\section{B A Institute of \\ YK Business Administration \\ 穼 \\ Karachi \\ Leadership and Ideas for Tomorrow}

\section{Business Review}

Volume 4 Issue 2 July-December 2009

7-1-2009

\title{
Role of Project Manager in design management
}

\author{
Shamas-ur-Rehman Toor \\ University of New South Wales, Sydney, Australia \\ Faisal Manzoor Arain \\ Southern Alberta Institute of Technology (SAIT), Calgary, Canada \\ Rubi Lai-Chua Suat Hong \\ CPG Consultants Pte. Ltd., Singapore
}

Follow this and additional works at: https://ir.iba.edu.pk/businessreview

Part of the Business Commons

\section{(c) (1)}

This work is licensed under a Creative Commons Attribution 4.0 International License.

\section{Recommended Citation}

Toor, S., Arain, F. M., \& Suat Hong, R. L. (2009). Role of Project Manager in design management. Business Review, 4(2), 7-20. Retrieved from https://doi.org/10.54784/1990-6587.1328

This article is brought to you by iRepository for open access under the Creative Commons Attribution 4.0 License and is available at https://ir.iba.edu.pk/businessreview/vol4/iss2/2. For more information, please contact irepository@iba.edu.pk. 


\title{
ARTICLE
}

\section{Role of the Project Manager in Design Management}

\author{
Shamas-ur-Rehman Toor \\ University of New South Wales, Sydney, Australia \\ Faisal Manzoor Arain \\ Southern Alberta Institute of Technology (SAIT), Calgary, Canada. \\ Rubi Lai-Chua Suat Hong \\ CPG Consultants Pte. Ltd., Singapore
}

\begin{abstract}
A project manager wears many hats including project leader, project facilitator, project mediator, project coordinator, project communicator, project promoter, project motivator and project controller. Complying with all these roles and sometimes reconciling with the competing demands of project stakeholders is not easy. Hence, for construction work, project managers must develop necessary skills to cater to the intricate and tricky situations for different construction projects. Many project managers pay a lot of focus on keeping the project on time and within budget - leaving design problems to the architect. Managing design is a challenging job which tests technical, personal, interpersonal, team building, management, and business skills of the project manager. However, a good project manager has an important role in design management of the project. The project manager must ensure that a clear and comprehensive brief is well established that can lead to an end product that satisfies the myriad requirements of aesthetics, functionality, economics, constructability, energy conservation and maintainability. Though not the designer, the project manager has to ensure the effectiveness of design and competence of the whole team involved in the design process. This article presents an overview of the role of the project manager with regard to design management for a project, particularly during the design stage. Discussion here also emphasizes the understanding of the design logic on part of the project manager for successful accomplishment the project.
\end{abstract}

Keywords: Design management, project manager, construction

\section{INTRODUCTION}

Construction is a complex industry in which disputes are common, uncertainties and risks are inevitable, individual interests of parties are natural, delays are routine and cause huge loss of resources, and aggravations are an everyday occurrence (Arain, et al., 2004; Toor and Ogunlana, 2008). Among the project players, project manager (PM) is the person who has to carefully look into all these matters and ensure that the project completes on time, within budget, and according to expected quality standards (Arain, 2005). Most of the disputes, as several researchers have established, are due to lack of communication and coordination interface management in the design phase (Arain and Low, 2005a). This deficiency leads to difficult access of working area and conflicts in the requirements of various subcontractors during construction, and a design that does 
not deliver an end product that satisfies the client. This coordination has to be established at the design stage and is the responsibility of designers and the project manager.

The fragmentation of the industry is exacerbated by the insularity of the professions, the separation of the design from the construction, the uniqueness of the projects and the ephemeral nature of the relationships, and project organization (Masterman, 2002; Arain and Low, 2003). This fragmentation is due to the increasing complexity of projects requiring people of many different specialist skills - brief formulation, space planning, architectural treatment, cladding design, interior design, acoustical design, structural steel design, many specialist mechanical and electrical systems, constructability, specification writer, etc.

In addition, internationalization of construction has given birth to numerous issues. A project in Thailand may be designed by a German firm, managed by an Italian firm, constructed by a joint venture of firms from different countries, using labor from Cambodia and Myanmar, and material suppliers from all over the world (Toor and Ogunlana, 2005). Clearly, internationalization further complicates an already complicated industry.

A good project manager should be capable of dealing with potential project circumstances, and prepared to deal with problems and repercussions of international establishments for projects. The project manager needs to be well aware of various practices in different regions of the world and must communicate the local customs and regulations to all parties involved. Design stage needs special attention in this regard (Arain and Low, 2005b). If the designers are not local, there is the major problem of communication with the Clients to understand what they want. In addition, since drawings have to be submitted to authorities for approval, designers must make sure that the design complies with local standards and regulations.

Also, designers and the project manager should consider the local construction practices, methods and available materials. Competence of local contractors and subcontractors who will carry out the construction must be given attention during design process. Design should also reflect the deliberation of future maintenance which should be easy for locals to carry out. All these aspects are vital. Although these aspects look simple and easy, yet the project manager should be able to totally appreciate these issues to make the project a success.

This paper makes an attempt to highlight the key role that the project manager plays with regard to the design management of the project. Discussion in this paper focuses on the very fact that the project manager acts as a design manager, design coordinator, communicator, conciliator, mediator, tram builder, and team motivator. Having all these responsibilities, the project manager is not a designer. Therefore, it is not the job of the project manager to dictate the design or force his opinion on design. 
Instead, the project manager should be able to lead the design team into a common direction and ensure that the design objectives are achieved.

\section{Design-Related Problems in Projects}

The design stage is relatively short compared to the full life cycle of a project, but has a large impact on the project (Arain and Low, 2005c). Also, most of the project failures are due to poor design as Palmer (1987) has established. Among one of the initial studies of problems on projects, Baldwin and Manthei (1971) cited several factors which result in delays on construction projects in United States; design changes, shop drawings, manufactured items, permits and building codes are among these factors. AlKhalil and Al-Ghafly (1999) reported that delay of project is a major problem in construction that leads to disputes and hostile relationship among different participants. Cheung et al. (2000) observe that if the problems and/or obstacles are not solved in time, they can cause delays and cost overruns in projects, harm cooperative relationships, reduce efficiency, lead to claims and disputes, and probably invoke litigation proceedings.

In the survey carried out by Odeh and Battaineh (2002), contractors and consultants agreed that owner interference, slow decision making and improper planning, are among the top ten most important factors for delays in construction projects with traditional type contracts. Mansfield et al. (1994) studied the causes of delay and cost overrun in construction projects in Nigeria. The results showed that improper planning, approval of shop drawings, design changes, conflicts in work schedules of subcontractors, slow decision making and executive bureaucracy in the owners' organizations and design errors are the most important problems causing delays in project in Saudi Arabia (Assaf, et al., 1994; Arain, et al., 2004). In a study of large construction projects in Vietnam, Long et al. (2004) grouped the top ranked problems in terms of occurrence as: (1) incompetent designers and contractors, (2) poor estimation and change management, (3) social and technological issues, (4) site related issues, and (5) improper techniques and tools.

Another study of construction delays in Indonesia by Kaming et al. (1997) concluded that design changes, inadequate planning, poor labor productivity and resource shortages were predominant factors for time delays. Chan and Kumaraswamy (1997) found that significant delay factors of construction projects in Hong Kong were: poor site management and supervision, unforeseen ground conditions, low speed of decision making involving all project teams, client-initiated variations and necessary variations of work. Toor and Ogunlana (2006) also found that the problems related to design were significant in their study of the problems of the Second Bangkok International Airport project. They found that four of the top 20 problems in the problem inventory of 75 problems were design-oriented.

It is obvious from earlier research that design-related problems are of vital 
nature and result in heavy losses at subsequent stages. Some studies have revealed that more than half of the construction projects overrun on both budget and time at completion and these problems largely occur due to design changes, scope changes and omissions and corrections in design (Arain and Low, 2006d). If design is carried out systematically with correct methodology, chances of variations and corrections would certainly reduce. The project manager should try to anticipate any potential changes which could harm the project objectives. If design is correctly done, chances of variations are reduced and hence there is an increase in the likelihood of completion of project in time and within budget.

\section{Why is the project manager a vital factor?}

Researchers and practitioners have emphasized the fact that the project manager is the key player in projects. Belout and Gauvreau (2004) are of the view that the project manager plays a crucial and central role in leading the project to a success. In many earlier research works, the project manager has been ranked among the top critical success factors for project (Ashley et al., 1987; Toor and Ogunlana, 2005; Nguyen, et al., 2004). Being project leader, the project manager has to fulfill the roles of facilitator, coordinator, motivator and politician on projects (Briner, et al., 1996). Performing these complex jobs demands a competent leader who can interact within and across several participant groups. This challenging and complicated role of the project manager has necessitated the development of more sophisticated approaches to managing the performance of project managers (Dainty, et al., 2003).

Learning from the past projects is very important because the professionals could improve and apply their experience in the future (Arain and Low, 2006a). No projects can be executed without people. Not even the purest, technical construction project. And the more the world moves into the knowledge society, the more obvious it is that managing people in projects is equally important as managing the technical and financial side as shown in Figure 1 (Arain and Low, 2006b). But this soft people approach must not be so focused that one forgets that projects after all is to come up with hard technical and financial solutions to a problem. The problem is to handle both sides equally well, realizing that soft and hard values can be very difficult to combine.

Many researches suggest a combined structure-and-culture approach to modern project management. It is important for project manager to understand how a balanced project leadership attitude should work to identify the potential problem areas which should be getting immediate attention at any point in time during modern project execution (Arain and Low, 2006b). Project managers should eventually inculcate all the factors presented in the theoretical model for effective management of building projects as shown in Figure 1.

Belassi and Tukel (1996) have also emphasized on the competence of the 
project manager as critical factor affecting project planning, scheduling and communication. Long et al. (2004) have shown that 'competent project manager' was the top critical success factor as rated by owners, consultants and contractors in a study of large construction projects in Vietnam. Muns and Bjeirmi (1996) have also supported the idea that success or failure of project management in certain projects is highly dependent on the choice of the project manager.

Flowers (2002) emphasizes that possessing technical skills alone are not important for engineers, developing the leadership skills is also vital for engineers if they want to significantly contribute to future. A project manager should have a good understanding of all aspects, which may involve diversity of culture, religion, language, nationality, and region. He should also be able to communicate this understanding clearly among these clusters. All sensitivities, limitations and capabilities of project team members should be understandable to him.

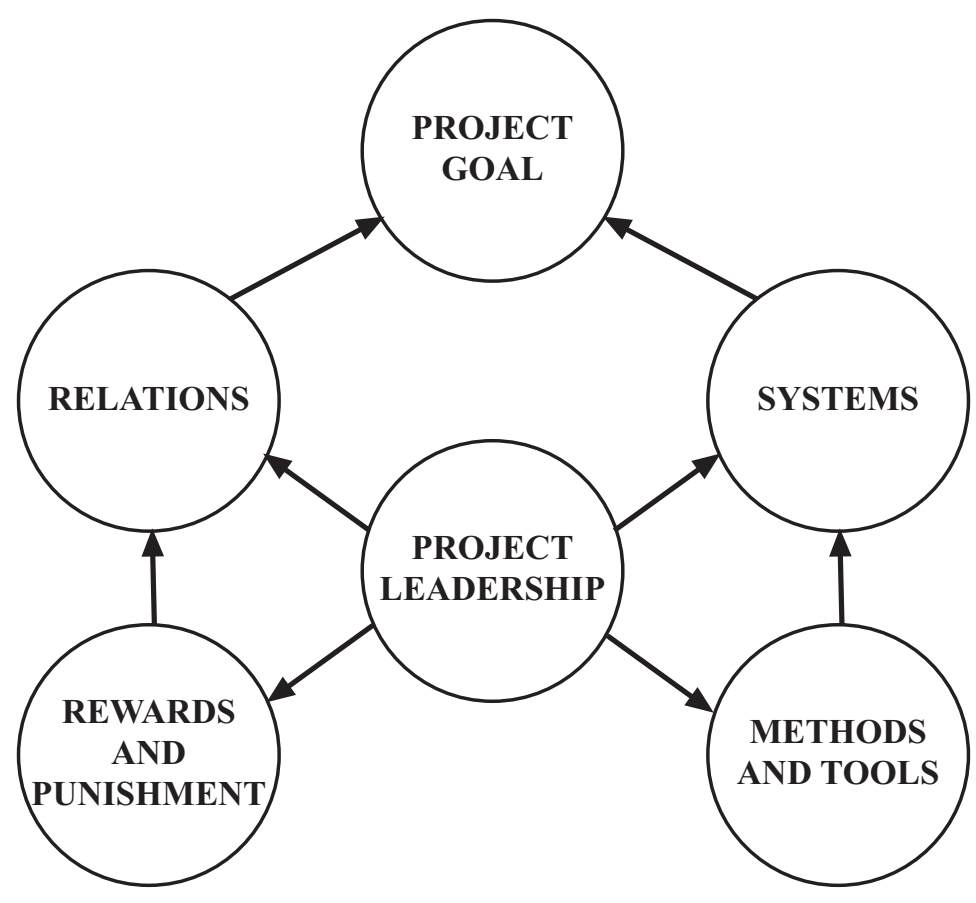

Figure 1 Theoretical model for effective management of building projects 


\section{Project Manager and Design Process}

As it has been discussed above that the project manager is the overall in charge of the project, and managing the design is one of the important tasks he has to perform. Managing design is a multifaceted task and needs. The project manager has to clearly understand the client's needs so that he is certain about what he is going to deliver as a final product. Also, he should be able to manage the whole design team which includes various designers performing their specific tasks. Moreover, he has to communicate and coordinate among all stakeholders so effectively that no ambiguities are left on any side (Arain, 2005). Capturing the client's requirements, communicating them to designers, making sure that design is complete in all respects and has been well coordinated among all designers, all modifications and changes have been appropriately incorporated and client has been informed about the outcomes of such changes are the duties of the project manager during the design stage.

Project manager's role with regard to design includes:

- Helping the client to understand their requirements and capturing the requirements in a Brief

- Communicating the client's requirements to all designers

- Communicating the concerns of designers to the client and obtaining feed back

- Coordinating among various designers and building a strong team atmosphere

- Resolving the potentially conflicting requirements of various stakeholders

- Making sure that design complies with local laws and regulations

- Making decisions on alternative solutions to a problem

- Making sure that design complies to the budget and time constraints

- Making sure that all special constraints, requirements and expectations have been considered in design

- Checking that there are contractors of adequate capability to construct the design

- Making sure that design incorporates the concept of value management

- Analyzing the build-ability (constructability) and practicality of design

- Forecasting the design related risks during the construction stage

- Checking that design requirements are clearly specified for the local/working contractors

- Checking that appropriate work interfaces have been developed for various contractors

- Checking that phasing (if required) has been considered on a project

- Checking that future maintenance has been considered in the design

- Checking the availability of materials locally (or making the alternate arrangement for material procurement) 
- Checking that design caters for future changes, alterations, extensions, if required

Although the project manager has to ensure that design considers all points stated above, the generic role of the project manager is discussed in more detail in the following sections.

\section{Project Manager and Technical Skills}

Researchers have ascertained that having technical expertise alone is not enough for a project manager to be successful on projects. He should have other soft skills like personal and interpersonal skills, communication skills, organizational and management skills, business skills and leadership skills. However, having no technical knowledge is also not recommended for better performance on complex projects. Having no technical knowledge can not be an excuse in case of failures which are likely in multifarious project environment. Therefore, a project manager should also be well conversant with technicalities of design. He should be able to understand the complete design process so that he can manage it meticulously. Many researchers are of the view that project managers with technical skills have a big advantage for the successful completion of complex construction projects.

It is not compulsory that all construction projects are newly created and that one has to develop a project from the scratch till the completion (Arain, et al., 2004). According to a survey in UK, over forty percent of the construction works were refurbishment works in 1996 (Egbu, 1999). Therefore, having design and technical expertise for refurbishment works is crucial for success in rehabilitation works where the project manager has to give technical input for completion of project within budget and on time.

\section{Project Manger is not the Designer}

Important leadership skills for effective project management include team skills, communication skills, personal and interpersonal skills, technical skills and project management skills. Evidently, success of effective project managers does not necessarily lie in their technical skills alone. A good project manager has to develop more human qualities to be successful on today's truly international projects.

However, it is important that the project manager realize his/her actual role that is managing and leading the design, not carrying out the actual design. If the project manager takes over the design responsibility, designers are confused of their roles and therefore will not be able to perform to their optimum potential. Following dictation rather than following the problem and seeking solution is not designers' job. If the project manager takes of the design role, creativity of the designer cannot be displayed with liberty and confidence. Therefore, the project manager should be careful not to 
take over the design. The project manager's role is to concentrate on the bigger picture, design outcomes, and project objectives. The project manager should intervene if he/she feels that the designers are not following the project objectives or when the design is too creative to be practical.

\section{Project Manger as Communicator}

Communication is one of the most important success factors on projects (Toor and Ogunlana, 2008b). Especially in today's world, when designers, contractors and clients are involved in global projects and communicate through modern technological tools, communication plays an even more important role. Various researchers (Chan, et al., 2001; Chua, et al., 1999) have emphasized on adequacy of communication for success of projects. In addition, Millet (1999) is of the view that breakdown of communication among the stakeholders is one of the major causes of failures of projects. Some researchers have observed that most conflicts occur due to lack of communication and coordination interfacing (Arain and Low, 2003). Others argue that lack of communication may create a confrontational situation at times, such as when the client does not agree with the planned work tasks (see: Zipf, 1998; Arain and Low, 2005d).

The need for good communication is especially important for the project manager. He must ensure that all parties are involved in the project and communicating effectively during all stages of the project. The project manager acts as a liaison among various stakeholders. He has to work with the many parties within the client's organization to establish their collective (and often conflicting) requirements. The establishment of the brief is critical, and without a good brief, it is unlikely that a good design would be developed that would satisfy the client. The role of the project manager during this brief formation stage cannot by over-stated, and is one of his prime roles in design management.

After establishing the brief, the project manager has to communicate the requirements of the client to the designers, and help ensure good communication between the various designers. He has to ensure instructions of designers to contractors are given effectively, and concerns of contractors are communicated back to client and designers. Therefore, he should develop adequate channels of communication between all parties. This is particularly important with regard to changes in design (Arain and Low, 2005c). Since design stage is the time when most of the changes take place, communicating these changes and informing all designers (architectural, structural, M\&E and specialty designers) about latest updates is vital, and informing the client of the time and cost implication of such changes.

\section{Project Manger as Coordinator}

Cheng et al. (2003) have strongly focused on improved coordination in 
construction projects especially those with relatively long periods. Cooperation among clients, designers, consultants, contractors, and suppliers, results in a project with least conflicts, improved costs and schedules. Most project mangers are aware that projects are built up of tasks which consist of numerous activities. When these activities are shared by more than one discipline, it is necessary to obtain agreement among parties to proceed. Disagreement or conflict can exist not only among engineers but also between engineers and the organizations whose procedures they are obliged to follow (Conroy and Soltan, 1997). Cheng et al. (2003) have concluded that due to numerous working interfaces, complicated networks, and diversified team members of large construction projects, coordination efficiency among members of construction team is vital to the success of the projects.

Being at the centre of the decision making, the project manager is responsible for coordinating all major and minor activities on a project. He is overall head of project and therefore has to keep the responsibility or appropriate coordination among various stakeholders. Need of coordination is felt the most during design stage when different designers are designing various aspects of projects at their own places. They have their own constraints and requirements on design. Appropriate coordination among architects, structural engineers, M\&E engineers and other specialist designers reduces the chances of conflicts for later stages. The project should also make sure that designers have understood what they are going to design and the final outcome is fully conforming to the client's requirements. Moreover, facilitating the interaction among various designers to bring a consensus on design is a vital trait and crucial duty of the project manager. Assisting interaction among several team members, getting all of them on a track towards the success of project and resolving differences among them are characteristics of a successful project manager.

\section{Project Manager as Controller}

The project manager has an important role in setting a program and budget for the project, and controlling activities to ensure that these are adhered to. This is particularly important for design activities. He has to track the progress of design to ensure the designers are following the program, that the necessary presentations are made, and that the client confirms acceptance within key milestones. He has to ensure the necessary consultations are made with authorities, and advices from required specialists are obtained. He has to ensure that the design is within budget by getting updated cost estimates at relevant times, and get the design checked for energy conservation, build-ability, maintainability, etc. He has to track all changes, to ensure that they do not deviate from the brief and do not jeopardize the approved program and budget. 


\section{Project Manger as Mediator/Conciliator}

Aggravations and conflicts are now accepted norms in construction projects. A project manager, therefore, needs to manage different disagreements which occur among various design specialists. Conflict may also occur among different parties involved in the project and the project manager should be able to find a way for resolution. Contractors may not agree to the solution of designers on a particular issue. Users might not like the design or even client might be undecided about the final design. Potential of conflict due to varied requirements of different designers is also high on construction projects. A common dispute is among architects and structural designers. Architects often design structures which are hard and complex for structural engineers to design. Similarly, there may be conflict during construction when the designer wants a detail achieved at great cost to the contractor. Here comes the project manager into play while he/she tries to find a solution which is acceptable to all. Conflict resolution, mediation and conciliation must not be considered as win-lose task. The project manager should be astute enough to find the winwin solutions for related stakeholders in order to achieve successful project completion.

\section{Project Manager as Team Builder and Motivator}

Design is successful if the whole team gives its inputs and every member performs his job with commitment to reach the project goals. The project manager acts as a liaison among various teams of designers, as an overall team builder and motivator. He inspires all team members to perform the complex and tedious jobs and keeps them together during all stages, focused on project objectives and ambitions. Team building is one of the crucial factors for the project manager to successfully manage the design and the project at large. All team members should have a shared vision for the project, and motivation to fulfill the project aspirations. That is when the team members will give their best input and try to go beyond their potential to achieve the project goals.

\section{Conclusions}

The project manager is unquestionably crucial and central actor in a construction project. His/her effective and efficient role during all stages of project is vital for project success. Though the role of the project manager is commonly understood at project level, it has been often ignored in terms of design management. Effective and efficient design management can make a significant difference in how the project objectives are met. A project manager does not perform the design must not take over the designer's work. Rather, he should ensure that all requirements are being met and design caters to the client's demands and needs. Keeping the whole team informed, integrating the design effectively, motivating the team members and finally meeting the objectives of 
project are his prime tasks. In addition to having soft and management skills, it is therefore advantageous for a project manager to be well conversant with technical design and design process and its logical flow.

In summary, the project manager is the key to success of construction project. $\mathrm{He}$ acts as 'an extra eye' on the project design and ensures that project ambitions are thoroughly considered during design. Although he does not design himself, he must understand the design process, recognize what matters should be given priority and what factors should be considered at various steps. With attention to design, the project manager can help to ensure that the project is delivered not only within time and budget, but also designed to fully meet the client's needs and satisfaction. The issues discussed would assist management professionals in grooming their skills and taking proactive measures for effective management of projects in general.

\section{REFERENCES}

Al-Khalil, M. I. and Al-Ghafly, M. A. (1999). Important Causes of Delay in Public Utility Projects in Saudi Arabia. Construction Management and Economics, Vol. 17, No. 5, pp 647-655.

Arain, F.M. and Low, S. P. (2003). Measures for minimizing adverse impact of variations to institutional buildings in Singapore, Journal of Housing, Building and Planning, Vol. 10, No. 1, pp.97-116.

Arain, F. M., Assaf, S. and Low, S. P (2004). Causes of discrepancies between design and construction. Architectural Science Review, Vol. 47, No. 3, pp. 237-249.

Arain, F. M. (2005). Potential barriers in management of refurbishment projects. Journal of Independent Studies and Research, Vol. 3, No. 1, pp. 22-31.

Arain, F. M. and Low, S. P. (2005a). How design consultants perceive potential causes of variation orders for institutional buildings in Singapore. Architectural Engineering and Design Management, Vol. 1, No. 3, pp. 163-178.

Arain, F. M. and Low, S. P. (2005b). Potential effects of variation orders on institutional buildings: Developers' perspective. Facilities, Emerald, Vol. 23, No. 11, pp. 496-510.

Arain, F. M. and Low, S. P. (2005c). The nature and frequency of occurrence of variation orders for educational building projects in Singapore. International Journal of Construction Management, Vol. 5, No. 2, pp. 79-91. 
Arain, F. M. and Low, S. P. (2005d). Lesson learned from past projects for effective management of variation orders for institutional building projects, Proceedings of the MICRA 4th Annual Conference, Kuala Lumpur, Malaysia, pp. 10-1 to 10-18, ISBN: 9831002539.

Arain, F.M. and Low, S. P. (2006a). Developers' view of potential causes of variation orders for institutional buildings in Singapore. Architectural Science Review, Vol. 49, No. 1 , pp. $59-74$.

Arain, F. M. and Low, S. P. (2006b). Value Management through a knowledge based decision support system for managing variations in educational building projects. International Journal of Construction Management, Vol. 6, No. 2, pp. 81-96.

Ashley, D. B., Lurie, C. S., and Jaselskis, E. J. (1987).. Determinants of Construction Project Success. Project Management Journal, Vol. 18, No. 2, pp 69-77.

Assaf, S. A., Al-Khalil, M. and Al-Hazmi, M. (1995). Causes of delay in large building construction projects. Journal of Management in Engineering, ASCE, Vol. 11, No. 2, pp. $45-50$.

Baldwin, J. R. and Manthei, J. M. (1971). Causes of delays in the construction industry. Journal of Construction Division, ASCE, Vol. 97, pp. 177-187.

Belout, A and Gauvreau, C. (2004). Factors Influencing the Project Success: The impact of human resource management. International Journal of Project Management, Vol. 22, $1-11$.

Belassi, W, and Tukel, O I (1996). A New Framework for Determining Critical Success/Failure Factors in Projects. International Journal of Project Management, Vol. 14, No. 3, 141-151.

Briner, W., Hastings, C., and Geddes, M. (1996). Project Leadership. Gower, Aldershot, England.

Chan, D. W. M. and Kumaraswary, M. M. (1997). A Comparative Study of Causes of Time Overruns in Hong Kong Construction Projects. International Journal of Project Management, Vol. 15, No. 1, pp. 55- 63.

Chan, A. P. C., Ho, D. C. K., and Tam, C. M. (2001). Design and Build Project Success Factors: a Multivariate analysis. Journal of Construction Engineering and Management, ASCE, Vol.127, No.2, pp. 93-100. 
Cheng, M. Y., Su, C. W., and You, H. Y. (2003). Optimal Project Organizational Structure For Construction Management. Journal of Construction Engineering and Management, ASCE, Vol. 129, No.1, pp. 70-79.

Cheung, S. O., Tam, C. M., Ndekugri, I. and Harris, F. C. (2000). Factors affecting clients' project dispute resolution satisfaction in Hong Kong. Construction Management and Economics, Vol. 18, No. 3 pp. 281-294.

Chua, D.K.H., Kog, Y.C. \& Loh, P.K. (1999). Critical success factors for different project objectives. Journal of Construction Engineering and Management, Vol. 125, No. 3, pp $142-150$.

Conroy, G., \& Soltan, H. (1997). ConSERV, a methodology for managing multidisciplinary engineering design projects. International Journal of Project Management, Vol. 15, No. 2, pp 121-132.

Dainty, A. R. J., Cheng, M I and Moore, D R (2004). A Competency-Based Performance Model for Construction Project Model. Construction Management and Economics, Vol.22, No.8, 877-888.

Egbu, C. O. (1999). Skills, knowledge and competencies for managing construction refurbishment works. Construction Management and Economics, Vol. 17, No. 1, pp. 29-43.

Flowers, R. B. (2002). Leadership as a Responsibility. Leadership and Management in Engineering, Vol. 2, No. 3, pp 15-19.

Kaming, P. F., Olomolaiye, P. O., Holt, G. D. and Harris, F. (1997) Factors influencing time and cost overruns on high-rise projects in Indonesia. Construction Management and Economics, Vol. 15, No. 1, pp. 83-94.

Loosemore M, Lee, P (2002). Communication Problems with Ethnic Minorities in Construction Industry. International Journal of Project Management, Vol. 20, No. 3, pp 517-524.

Long D. N., Ogunlana, S. O. and Lan, D. T. (2004). A Study on Project Success Factors on Large Construction Projects in Vietnam. Engineering, Construction and Architectural Management, Vol. 11, No. 6, pp 404-413.

Mansfield, N.R., Ugwu, O.O. and Doran, T. (1994). Causes of delay and cost overruns 
in Nigerian construction projects. International Journal of Project Management, Vol. 12, No 4, pp. pp 254-260.

Masterman, J.W.E. (2002). An Introduction to Building Procurement Systems, 2nd ed., Spon Press, London

Millet, R. A. (1999). Failures: How to avoid them. Journal of Management in Engineering, ASCE, Vol. 15, No.1, pp. 32-36.

Munns, A K, and Bjeirmi, B F (1996). The role of project management in achieving project success. International Journal of Project Management, Vol. 14, pp 81-87.

Palmer, C. F. (1987).. Matrix approach to project planning design and management. Project management journal, Vol. 5, No. 3, pp 162-166.

Odeh A.M. andÊBattaineh H.T. (2002). Causes of construction delay: traditional contracts. , Vol. 20,ÊNo. 1, pp. 67-73

Toor, S. R. and Ogunlana, S. O. (2005). What is Crucial for Success: investigating the critical success factors and key performance indicators for mega construction projects. Annual Symposium, Project Management Institute, Singapore Chapter, October 12, 2005.

Toor, S. R. and Ogunlana, S. O. (2006). Conquering the construction battle: Overcoming the problems on the large construction projects. Proceedings of the International Conference in the Built Environment 2006, Kuala Lumpur, Malaysia, June 13-15.

Toor, S. R and Ogunlana, S. O. (2008). Problems causing delays in major construction projects in Thailand. Construction Management and Economics, Vol. 26, No. 4, pp. 395-408.

Toor, S. R and Ogunlana, S. O. (2008). Critical COMs of success in large-scale construction projects: Evidence from Thailand construction industry. International Journal of Project Management, Vol. 26, No. 4, pp. 420-430.

Zipf, J. P. (1998). An Integrated Project Management System. Journal of Management in Engineering, ASCE, Vol. 14, No.3, pp. 38-41. 